Afric

ArXiv

Article title: STRATEGIC LEADERSHIP AND SERVICE DELIVERY IN ORGANIZATIONS: A CRITICAL REVIEW OF LITERA` Authors: Vitalis Ragul[1]

Affiliations: University of Nairobi, Faculty of Business and Management Science, Department of Business Administration[1]

Orcid ids: 0000-0002-3444-1125[1]

Contact e-mail: vitalisomondi@gmail.com

License information: This work has been published open access under Creative Commons Attribution License http://creativecommons.org/licenses/by/4.0/, which permits unrestricted use, distribution, and reproduction in any medium, provided the original work is properly cited. Conditions, terms of use and publishing policy can be found at https://www.scienceopen.com/.

Preprint statement: This article is a preprint and has not been peer-reviewed, under consideration and submitted to AfricArXiv Preprints for open peer review.

Funder: Self

DOI: $10.14293 / 111.000 / 000022 . v 1$

Preprint first posted online: 19 November 2021

Keywords: Strategic leadership, Service delivery, Public sector, Citizens 


\section{STRATEGIC LEADERSHIP AND SERVICE DELIVERY IN ORGANIZATIONS: A CRITICAL REVIEW OF LITERATURE}

Author: Vitalis Omondi Ragul

ORCID Identifier: 0000-0002-3444-1125

Full ORCID iD and link to my public records: https://orcid.org/0000-0002-3444-1125 


\begin{abstract}
Strategic leaders need to be certain about what they want to achieve for the organization. Efficient and effective leaders develop strategies and structures that are clear and work with employees that adhere to good ethical practices that enable the organizations to achieve set goals. Strategic leadership is important to all organizations, whether in public and private sector, albeit in different contexts. This paper sought to critically review literature on the link between strategic leadership and service delivery in organizations. Several theories were reviewed, namely upper echelons perspective, strategic leadership theory, principal agency theory and new public management theory. A conceptual framework was developed to provide the basis of the identified theories with a view to explaining and predicting the variables through definition of the contents and attributes of those theories. Strategic leadership was conceptualized as the independent variable while service delivery in organizations was hypothesized as the dependent variable. Conceptual and empirical studies were undertaken to examine the existing literature in strategic leadership as well as service delivery. Arising from the review, several knowledge gaps were identified. The study established that strategic leadership is applicable to all organizations with an increasing number of organizations continually embracing it upon realizing that it is a key success factor in organizational performance and therefore in the delivery of service for the benefit of the public.
\end{abstract}

Key words: strategic leadership, service delivery, public sector, citizens. 


\section{INTRODUCTION}

Strategic leadership is increasingly taking center-stage in the running of organizations, driven by the need to learn, transform and impart management skills to improve performance (Boal \& Hooijberg, 2000). Organizations are complex and composed of interrelated systems. As such leadership ought to be focused and based on clear vision, action and careful decisions (Quong \& Walker, 2010). Besides envisioning and envisaging the direction of the organization over the longterm, strategic leadership is a flexible approach that empowers members of the organization to embrace strategic change as it occurs (Hitt, Ireland \& Hoskisson, 2007). Ireland (2007) contends that strategic leadership could turn out to be one of the most important issues that or-ganizations face. The achievement of improved performance by organizations will be greatly enhanced where strategic leadership is functional. Schette, Barkhuizen and Swanepoel (2014) maintain that strategic leadership empowers organizations to expect, plan and show flexibility. Joyce (2012) contends that strategic leadership unambiguously defines the purpose of the organization by providing a clear pathway towards strategy formulation and succeeds on conditions of flexibility making it amenable to changes in the environment. This quality makes strategic leader-ship multifunctional as it aligns the internal competencies of the organization to the external environment (Simsek, Jansen, Minichilli \& Escriba-Esteve, 2015). Strategic leadership is therefore a key success factor in organizations and can contribute to enhanced service delivery.

\section{The Concept of Strategic Leadership}

Strategic leadership lends itself to the argument that good leaders work with strategies, clear structures and good ethical practices to enhance delivery of service, particularly in the public sector (Allio, 2015). Early scholars referred to strategic leadership as determination of where an organization was going and how it would get there (Cheng, 2000). It was considered a concern of leaders, mainly the senior management, who engaged in strategic and long range planning. The management functions of planning, organizing, directing, staffing and controlling were also regarded as strategic. Over time, strategic leadership has advanced beyond vision statements and plans (Quong \& Walker, 2010). Rowe (2001) describes strategic leadership as the capacity of leaders to sway others to make decisions that will contribute to improving the organizations in the long term while ensuring that the organizations remain stable in the short term. A key plank of this definition is the deliberate effort by the leader to chart a long-term direction for the organization. For example, in the wake of the invasion of Covid-19 pandemic, policy makers and researchers alike are wondering whether there is need to reexamine leadership in totality and evolve new models, approaches and practices that would reassure the populace in times of uncertainties and instability. Farhan and Wright (2021) argue that to improve leadership effectiveness in times such as these, it is important to adopt approaches that can make a difference in people's lives and wellbeing. Hence the need for strategic leadership. Thus, a strategic leader is expected to be a source of inspiration, hope, resilience and unrelenting to drive the implementation of the organization's strategy, thinking strategically how activities being executed will impact the future while reassuring and rallying team members to individually contribute to achievement of organizational objectives. From this review, it is evident that strategic leadership is critical in the establishment and growth and development of an organization's philosophy. An increasing number of writers are agreed that organizations with strategic focus are those that not only embrace strategic methods including strategic planning, but also practice strategic leadership (Davies, 2008). 


\section{Service Delivery}

This concept is applicable in provision of social goods such as roads, classrooms and other social benefits rather than the provision of outcomes like poverty alleviation, road safety and improvement of literacy levels. In this study, service delivery is defined as continuous cyclical activity that develops and delivers customer-focused services. The public sector exists to deliver services to the people. Riekert (2001) argues that leaders in the public sector are obligated to provide services to the public. The delivery of service by the government is not simply aimed at enjoyment by the citizens, rather it is also about protecting the rights of citizens. It is therefore critical that the delivery of service to the public is evaluated against set performance targets which impact the lives of the citizens (Gaitho \& Awino, 2018).

\section{Strategic Leadership and Service Delivery}

Strategic leadership is about making decisions on services needed by the public in the public sector (Ireland \& Hitt, 2005). Strategic leaders focus on current stability of their organizations as well as future viability and therefore their decisions aim at promoting efficiency, better performance and improved delivery of service Naidoo (2011). Several writers on strategic leadership and service delivery cite poor management as a key contributor to poor service delivery. Joyce (2012), for example, argues that most organizations fail to provide services that meet the needs of the customers as they fall short of meeting the quality standards and they are not available in the right quantities and at the right prices. Wart (2003) maintains that effective leadership has inbuilt mechanisms that engender the delivery of superior goods and services more efficiently by ensuring that the vision of the organization is aligned to the environment thus allowing creativity and innovations to prosper. Jiwan (2016) argues that a well-functioning public sector is one that provides citizens with high quality services that are consistent with their needs. To deliver services efficiently and effectively therefore, strategic leaders should consider investing in human resource development to equip their staff with the requisite competencies to enhance skills, motivate the employees and ultimately make them more productive.

\section{THEORETICAL PERSPECTIVE OF THE STUDY}

Several theories inform this paper. These are; Upper Echelons Perspective, Strategic Leadership theory and Principal Agency theory. A review of these theories reveal a common thread - task, people and development - that runs across when viewed against the background of effective leadership and service delivery (Sanders \& Davey, 2011).

Upper Echelons Perspective postulates that the performance of organizations is predicated on the qualifications and experience of Top Management Team (TMT). The effectiveness of leaders as well as the strategies they deploy reflect their values and knowledge and leadership styles and qualities impact service delivery to the public (Hambrick \& Mason, 1984). This perspective lays the foundation for the role of strategic leaders in influencing organizational outcomes, and maintains that outcomes and strategic choices depend on top managers (Carpenter, Geletkanycz \& Sanders, 2004). Owing to the arguments put forth by exponents of the theory, the link between strategic leadership and service delivery continues to receive substantial attention from researchers with strategic leadership emerging as central in the realization of quality public service delivery (Gaitho, Ogutu, Awino \& Kitiabi, 2018). Equally, Narayanan and Zane (2018) argue that the impact of strategic leadership on the delivery of service extends to the external environment of the 
organization. However, the theory has been faulted for failing to study actual strategic leadership behavior. For example, Priem, Lyon and Dess (1999) disapprove of the use of demographic indicators as substitute for strategic leadership behaviours arguing that much of the research that linked strategic leadership behaviours to performance has created problems especially when construct validity is swapped with measurement validity.

Strategic Leadership theory developed from Hambrick and Mason's (1984) Upper Echelons theory. The goal of this theory was to investigate how top man-agement hierarchy influence strategic decision-making (Finkelstein and Ham-brick, 1996). Boal and Hooijberg (2000) progressed Hambrick's (1989) proposi-tion by arguing that strategic management is applicable in ambiguous, complex and turbulent environments with information glut. Strategic leadership therefore aims to develop and sustain learning to spawn change to equip managers with the ability to make the right decisions (Boal \& Hooijberg, 2000). Sev-eral models have emerged from strategic leadership theory. Key among these is Ireland and Hitt Strategic Leadership Model which positions employees at the center of the organization and argues a case of recognizing employees as an important resource and core competence.

Principal Agency theory presupposes that there is a conflict in terms of objectives to be achieved by the principal and agent (Eisenhardt, 1989). The principal is less risk-averse than the agent. In the public sector-setting, the principal is the citizen while the agent is the leadership whose responsibility is to manage resources to ensure that services are delivered to the citizens (Van Essen, 2011). Gaitho and Awino (2018) contend that this theory is applicable to leadership and service delivery as it describes the relationship between the players in public service delivery matrix.

The economic downturns that have been experienced by many economies have been caused by the inefficiencies in the public sector (Scott, 1982). The predominant line of thought is that private sector models are effective and are capable of providing solutions to the problems bedeviling governments. Early public service theories that were developed, including Scientific Management theory, proposed that governments should operate like business entities (Hartle, 1985; Waldo, 1948). Proponents of these theories were of the view that the in-troduction of business-related approaches in public sector administration would enhance service delivery. This gave rise to New Public Management (NPM) theory. The theory, mooted around 1980s, is predicated on the assumption that when governments operate as businesses, greater efficiency is realized and therefore improved service delivery to citizens (Costantinos, 2014). In recent times, Public Value theory has also emerged with proponents maintaining that governments need to focus on citizens, by paying attention to governance issues by incorporating public agencies to work with citizens to co-generate public value.

The trend of public service management and specifically governance, is increasingly becoming digital with the focus being integration of developmental issues into government control, an allencompassing government and use of web-based vehicles to capture data, store and communicate within government (Dunleavy \& Margetts, 2006). Hence the emergence of successor to NPM, Digital Era Governance whose centerpiece is integration of government functions with information and technology capabilities. Another recent model is New Public Governance, whose focus is 
concentration of decision-making, biasedness in staffing, politicization of public appointments and partisanship in the running of the government of the day (Aucoin, 2008).

\section{CONCEPTUAL AND EMPIRICAL STUDIES}

The conceptual framework of this paper provides the basis of the anchor theories and therefore explains and predicts the variables by defining the contents and attributes of the underlying theories. Several studies relevant to the topic of strategic leadership were reviewed and knowledge gaps identified. Almost all the papers were clear on the relationship between strategic leadership and public service delivery. This study conceptualizes strategic leadership as the independent variable while public service delivery is the dependent variable.

Gaitho et al. (2018), for example, sought to relate strategic leadership to service delivery of county governments in Kenya. The study used descriptive research and targeted all the 47 counties in Kenya, focusing on six departments that cover key sectors in the county economies. The services were in agriculture, education, health, public works, planning and natural resources. The study determined the extent of strategic leadership along five variables which were operationalized namely; influence, engagement, vision, motivation and reward. The findings revealed that the engagement between county leaders and their staff is high and is spawning growth and development in the counties and therefore giving the citizens hope and confidence in the economies and leadership. Gaitho and Awino (2018) in their study of Strategic Leadership and Service Delivery in African Context, examined the joint effect of strategic leadership and organization structure on service delivery, by focusing on 47 counties in Kenya as per the 2010 constitution. Just like Gaitho, et al. (2018), this study concentrated on six departments responsible for key sectors in the economies of the counties. Using multiple regression analysis, the study findings concluded that strategic leadership, organizational structure and ethical practices, when combined, have a significant influence on service delivery. In the study, Creating Public Service Excellence Applying Learning Organization Methods, which emphasized on the role of strategic leadership, Shutte and Barkhuizen (2014) sought to explore the extent to which a learning organization approach can impact public service efficiency and effectiveness. Strategic leaders from five major central government institutions were interviewed and grounded theory was used to analyze data. The findings brought out the need for public-sector leadership to continually scan the external environment to learn new and emerging trends in their areas of operation. Onder (2010) in investigating strategic management practice in the public sector in USA, and specifically examining the adoption of reinventing strategies, analyzed different strategies adopted by various states to reinvent government reforms. The study used descriptive research design to determine the differences in reform strategies across the 50 states that make up United States of America and found that the relationship between legislative party competitiveness and success of reinventing reform strategies is inverse.

Table 1: Summary of research gaps

\begin{tabular}{|c|c|c|c|c|c|}
\hline \multicolumn{2}{|c|}{ Researchers } & Focus & Methodology & Findings & Knowledge gaps \\
\hline $\begin{array}{l}\text { Gaitho } \\
\text { Ringii }\end{array}$ & $\begin{array}{r}\text { Peter } \\
\text { and }\end{array}$ & $\begin{array}{l}\text { Influence of } \\
\text { ethical } \\
\text { practices and }\end{array}$ & $\begin{array}{l}\text { Cross sectional } \\
\text { survey, primary } \\
\text { and secondary }\end{array}$ & $\begin{array}{l}\text { Strategic } \\
\text { leadership can } \\
\text { play a great role }\end{array}$ & $\begin{array}{l}\text { The study } \\
\text { conceptualized } \\
\text { strategic leader's }\end{array}$ \\
\hline
\end{tabular}




\begin{tabular}{|c|c|c|c|c|}
\hline $\begin{array}{l}\text { Awino Zachary } \\
\text { Bolo (2018) }\end{array}$ & $\begin{array}{l}\text { organizational } \\
\text { structure on the } \\
\text { relationship } \\
\text { between } \\
\text { strategic } \\
\text { leadership and } \\
\text { the delivery of } \\
\text { service by } \\
\text { county } \\
\text { governments in } \\
\text { Kenya. }\end{array}$ & $\begin{array}{l}\text { data collected } \\
\text { and analysis } \\
\text { done at both } \\
\text { descriptive and } \\
\text { inferential } \\
\text { statistics levels. } \\
\text { Multiple } \\
\text { regression used. }\end{array}$ & $\begin{array}{l}\text { in facilitating } \\
\text { service } \\
\text { delivery. }\end{array}$ & $\begin{array}{l}\text { influence in service } \\
\text { delivery in the } \\
\text { context of county } \\
\text { governments in } \\
\text { Kenya; does this } \\
\text { mirror the situation } \\
\text { at the National } \\
\text { government as a } \\
\text { composite of county } \\
\text { governments? }\end{array}$ \\
\hline $\begin{array}{lr}\text { Gaitho } & \text { Peter } \\
\text { Ringii, } & \text { Ogutu } \\
\text { Martin, } & \text { Awino } \\
\text { Zachary } & \text { Bolo, } \\
\text { and } & \text { Kitiabi, } \\
\text { Reginah } & (2018)\end{array}$ & $\begin{array}{l}\text { Relationship } \\
\text { between } \\
\text { strategic } \\
\text { leadership and } \\
\text { service delivery } \\
\text { of county } \\
\text { governments in } \\
\text { Kenya. }\end{array}$ & $\begin{array}{l}\text { Cross sectional } \\
\text { survey, } \\
\text { descriptive } \\
\text { research design. }\end{array}$ & $\begin{array}{l}\text { Strategic } \\
\text { leadership of } \\
\text { county } \\
\text { governments } \\
\text { greatly impacts } \\
\text { their service } \\
\text { delivery. }\end{array}$ & $\begin{array}{l}\text { Conceptualization of } \\
\text { variables as static } \\
\text { over a five year } \\
\text { period was based on } \\
\text { the assumption that } \\
\text { the measures had not } \\
\text { changed during this } \\
\text { period. This doesn't } \\
\text { give the true picture. } \\
\text { Also, the variables } \\
\text { under study were } \\
\text { mostly quantitative, } \\
\text { meaning the study } \\
\text { did not give room to } \\
\text { qualitative aspects } \\
\text { thus failing to } \\
\text { provide conclusive } \\
\text { results of effects of } \\
\text { variables studied. }\end{array}$ \\
\hline $\begin{array}{l}\text { Shutte Nico, } \\
\text { Barkhuizen } \\
\text { Nicolene, and } \\
\text { Swanepoel } \\
\text { Sonia (2014) }\end{array}$ & $\begin{array}{l}\text { Developing a } \\
\text { strategic } \\
\text { leadership } \\
\text { competency } \\
\text { measure for } \\
\text { strategic } \\
\text { leaders in South } \\
\text { Africa's public } \\
\text { sector. }\end{array}$ & $\begin{array}{l}\text { Cross sectional } \\
\text { survey, } \\
\text { exploratory } \\
\text { factor analysis } \\
\text { and descriptive } \\
\text { statistics } \\
\text { performed. }\end{array}$ & $\begin{array}{l}\text { Current } \\
\text { leadership } \\
\text { competencies } \\
\text { of public sector } \\
\text { leaders in South } \\
\text { Africa needs } \\
\text { improvement. }\end{array}$ & $\begin{array}{l}\text { This was cross } \\
\text { sectional survey. A } \\
\text { longitudinal survey } \\
\text { should be used to } \\
\text { determine strategic } \\
\text { leadership } \\
\text { competencies over } \\
\text { the long term. }\end{array}$ \\
\hline $\begin{array}{l}\text { Onder } \quad \text { Murat } \\
(2010)\end{array}$ & $\begin{array}{l}\text { Strategic } \\
\text { management } \\
\text { practice in } \\
\text { reinventing }\end{array}$ & $\begin{array}{l}\text { Descriptive } \\
\text { statistics, } \\
\text { multivariate } \\
\text { analysis and }\end{array}$ & $\begin{array}{l}\text { Different states } \\
\text { have reinvented } \\
\text { government } \\
\text { reforms }\end{array}$ & $\begin{array}{l}\text { The study did not } \\
\text { conclusively address } \\
\text { the question about } \\
\text { factors that }\end{array}$ \\
\hline
\end{tabular}




\begin{tabular}{|l|l|l|l|l|}
\hline $\begin{array}{l}\text { government in } \\
\text { reforms in } \\
\text { public sector in } \\
\text { states in USA. }\end{array}$ & $\begin{array}{l}\text { multiple } \\
\text { regression. }\end{array}$ & $\begin{array}{l}\text { differently i.e. it } \\
\text { varies from } \\
\text { state to state. }\end{array}$ & $\begin{array}{l}\text { contribute } \\
\text { adoption of strategic } \\
\text { reforms across the } \\
\text { states in the United } \\
\text { States. }\end{array}$ \\
\hline
\end{tabular}

\section{Source: Author (2019)}

\section{CONCLUSION}

Organizations are established to achieve specific set of goals. This responsibility fall on the strategic leader, who equipped with the capability to rally members of the organizations, should be able to inspire them and steer the organization to attain the predetermined goals. This means that strategic leadership bequeaths leaders the capacity to originate and reconstruct the purpose of the organization and what it exists to do. As Kirimi and Minja (2010) expound, strategic leaders guide the process of formulating vision, mission and strategies and well as implementing the strategies. There is a logical connection between effectiveness of leadership in the public sector and strategic leadership. Effective leaders ought to be familiar with the situation the organization is facing as well as the people they are leading. They also need to be confident, possess the skills to build alliances, coalitions and trust among the followers. In the public sector, strategic leadership is concerned with the changing trends of the performance of the organizations which is directly tied to internal organizational competencies and the changes in the external environment of the public sector organizations. Public service aims at meeting the needs of the citizens. The delivery of service is the process of production and dispatch of goods and services to the intended recipients, in this case the public (Universal Dictionary, 1961). Strategic leaders therefore play major roles in ensuring that resources are mobilized to deliver goods and services to a discerning public.

\section{ACKNOWLEDGEMENT AND FUNDING SOURCES}

I thank the Almighty God for His love, grace, provision and guidance. My gratitude also goes to my immediate family particularly my children, Natalie, Earl and Shiloh, who endured long hours of studies away from them. I could not get this far without the sacrificial and unceasing support from my supervisor, Professor Zackary Awino who guided me from the very conception of this paper and continues to guide me as I work on my proposal by encouraging, improving and ensuring that the paper meets the highest quality standards. Professor Martin Ogutu who was the moderator of this paper also deserves appreciation for his invaluable input. Lastly, I wish to appreciate Professor Jeremiah Muthama of University of Nairobi's Wangari Maathai Institute, brethren, colleagues, relatives and friends who have continued to encourage me as I continue with my studies. May God bless you all.

So far I have not benefited from funding from any external source. 


\section{REFERENCES}

Allio, R. J. (2015): Good strategy-good leaders. Strategy and Leadership, 43(5), 3-9.

Allison, G. T. (1982): Public and Private Management: Are they fundamentally alike in all unimportant respects? Current Issues in Public Administration. Ed FS Lane. St Martin's Press, New York, pp. 13-33.

Aucoin, P. (2008): New Public Management and the Quality of Government: Coping with the New Political Governance in Canada, Conference on "New Public Management and the Quality of Government", SOG and the Quality of Government Institute, University of Gothenburg, Sweden, 13-15, Nov2008, p. 14.

Baol, K. B., and Hooijberg, R. (2000): Strategic Leadership Research: Moving on. The leadership Quarterly, Vol. 11, issue 4, pp. 515-549.

Cheng, Y. C. (2000): Strategic Leadership for Educational Transformation in the New Millennium. Chulalongkorn Educational Review 6(2):15-32.

Costantinos, B. C. (2014): Theories of Governance and Public Management: Links to Understanding Welfare Policy Implementation.

Davies, B. (2008): Leading the Strategically Focused School. Keynote Paper to the ANTSEL Online Conference, 18-24 August. Video stream and paper available at www.cybertext.net.au/antsel_2008/tuesday.html (accessed 11 January, 2010).

Downs, G. W. and Larkey, P. D. (1986): The Search for Government Efficiency. Temple University Press, Philadelphia, PA.

Dunleavy, P. and Margetts (2006): New Public Management is Dead: Long Live Digital Era Governance. Journal of Public Administration Research and Theory.

Eisenhardt, K. M. (1989): Agency Theory: An Assessment and Review. The Academy of Management Review, Vol. 14, No. 1(Jan., 1989), pp. 57-74.

Elbanna, S., Andrews, R., and Pollanen, R. (2016): Strategic Planning and Implementation Success in Public Service Organizations. Evidence from Canada. Public Management Review, 18(7), pp. 1017-1042.

Farhan, B. and Wright, L. T. (2021). A New Strategic Leadership Model for Surviving and Coping: Lessons from Canada's leadership approach to Covid-19, Cogent Business and Management, 8:1.

Gaitho, P. R. and Awino, Z. B. (2018): Strategic Leadership and Service De-livery in the African Context: Does Organizational Structure and Ethical Practices Influence the Relationship? International Journal for Innovation, Education and Research. Vol. 6, No. 11, 2018.

Gaitho, P. R., Ogutu, M., Awino, Z. B. and Kitiabi, R. (2018): Strategic Lead-ership and Public Service Delivery of County Governments: The Kenyan Experience. International Journal of Economics, Commerce and Manage-ment. Vol. VI, Issue 11, November 2018, pp. 31-42. 
Geldenhuys, C. A. and Veldsman, T. H. (2011): A Change Navigation-based, Scenario Planning Process within a Developing World Context from an Afro-Centric Leadership Perspective. SA Journal of Human Resource Manage-ment, Vol. 9. Issue 1. pp. 1-17.

Giddens, A. (1998): The Third Way: The Renewal of Social Democracy. Polity Press.

Hartle, T. W. (1985). Sisyphus Revisited: Running the Government like a Business. Public Administration Review. 45, pp 341-351.

Hitt, M. A., Ireland, R. D. \& Hoskisson, R. E. (2007): Strategic Management: Competitiveness and Globalization: Concepts and Cases. 7th ed. South-Western: Cangage learning.

House, R. J., and Shamir, B. (1993): Toward the Integration of Transformational, Charismatic and Visionary Theories. San Diego, CA: Academic Press.

Ireland, R. D. and Hitt, M. A., 2005: Achieving and Maintaining Strategic

Competitiveness in the 21st Century: The Role of Strategic Leadership. Academy of Management Executive, 19: 63-77.

Jiwan, W. I. (2016): Determinants of Effective Service Delivery in the Pub-lic Sector: A Case of the Huduma Centre Programme in Mombasa County, Kenya. Unpublished Research Project Submitted in Partial Fulfilment for the Requirements for the Award of Master of Arts Degree in Project Man-agement and Planning, University of Nairobi.

Joyce, P. (2012): Strategic leadership in Public Services. Routledge.

Kirimi, A. and Minja, D. (2010): Transformational Corporate Leadership. Wake Forest, NC: IPI Publishers.

Kotze, M. and Nel, P. (2015): The Influence of Trait-emotional Intelligence on Authentic Leadership. SA Journal of Human Resource Management. 13(1), pp.1-9.

Leah, L. W. (2012). The Relationship between Strategic Leadership and Strategic Alignment in High Performing Companies in South Africa. Unpublished Doctoral Dissertation, Graduate School of Business Leadership, University of South Africa, South Africa.

Lussier, R. and Achua, C. (2007): Effective Leadership. Ohio: Thompson Higher Education.

Mahembe, B., and Engelbrecht, A. S. (2013): The Relationship between Ser-vant Leadership, Affective Team Commitment and Team Effectiveness. SA Journal of Human Resource Management, 10(1), pp. 1-9.

Maor, M (1999): The Paradox of Managerialism. Public Administration Re-view, Vol. 59, No.1 (Jan. - Feb., 1999), pp. 518.

Matshabaphala, M. D. J. (2007). Strategic Leadership Challenges for Service Delivery in South Africa. Journal of Public Administration, Vol. 42, Issue 3, Aug. 2007, pp. 241-249.

Moulder, P. (2017): Bureaucratic Theory by Max Weber. Retrieved on April 16, 
2020 from ToolsHero: https://www.toolshero.com/management/bureaucratic-theory-weber.

Naidoo, G. (2011): Adopting an Appropriate Leadership Approach to Improve Public Service Delivery in South Africa. African Journal of Public Affairs, Vol. 3 No. 3, December 2011.

Narayanan, V. K. and Zane, L. J. (2009): Inventing a Future for Strategic Leadership: Phenomenal Variety and Epistemic Opportunities. Journal of Strategy and Management, 2 (4), pp. 380-404.

Nut, P. C. and Backoff, R. W. (1993): Organizational Publicness and its Implications for Strategic Management. Journal of Public Administration Research and Theory. J-PART, Vol. 3, No. 2. pp. 209-231.

Olaka, H. O. (2016): Strategic Leadership and Implementation of Strategy in Commercial Banks in Kenya. Unpublished Dissertation Report Submitted to Chandaria School of Business in Partial Fulfillment of the Requirement for the Degree of Doctor of Business Administration, United States International University-Africa.

Onder, M. (2010): An Application of Strategic Management to the Public Sec-tor: What Accounts for the Adoption of Reinventing Government Strategies across the States of the United States. The Proceedings of 6th International Strategic Management Conference, July 8-10, 2010, St Petersburg, Russia.

Organization for Economic Co-operation and Development (2013): Government at a Glance 2013. OECD Publishing.

Priem, R. L., Lyon, D. W., and Dess, G. G. (1999): Inherent limitations of Demographic Proxies to Top Management Team Heterogeneity Research. Journal of Management, 25(6), pp. 935-953).

Quong, T. and Walker, A. (2010): Seven Principles of Strategic Leadership. ISEA, Vol. 38, Number 1.

Riekert, D. (2001): Batho Pele/Customer Care. Course in Effective Service Delivery: Enhancing the capacity of Existing and Emerging Public Service Managers for Effective Public Service Delivery. Unpublished course notes.

Rowe, W. G. (2001): Creating Wealth in Organizations: The Role of Strategic Leadership. Academy of Management Executive, 15, 81-94.

Sander, T. and Davey, K. S. (2011): Out of the Leadership Theory Jungle: A Proposed MetaModel of Strategic Leadership. Allied Academic Interna-tional Conference, pp. 41-46. Orlando Florida: DreamCathers Group LLC.

Scott, B. R. (1982): “Can Industry Survive in the Welfare State?” Harvard Business Review. 60, pp. 70-84.

Schette, N., Barkhuizen, N., and Swanepoel, S. (2014). A Strategic Leadership Competency Model for the South African Public Service. 6th International Conference on Humanities, Geography and Economics (ICHGE’2014) Nov.27-28. Cape Town, South Africa. 
Sila, H. M. and Gichinga, L. (2016): Role of Strategic Leadership on Strategy Implementation in Public Universities in Kenya - A Case Study of JKUAT Main Campus. International Journal of Innovative Research, 5(6), pp. 216-239.

Tan, U. (2006): Psychomotor Theory: Mind, Brain, Body Triad in Health and Disease. NeuroQuantology, 4(2), pp. 101-133.

Waldo, D. (1948): The Administrative State. Ronald Press, New York.

Wart, M. V. (2003): Public Sector Leadership Theory: An Assessment. Public Administration Review. 63(2), pp. 214-228.

World Bank (2018): Indicators of Citizen-Centric Public Service Delivery.

Wyld, H. C. Ed. (1961): The Universal Dictionary of the English Language. London: Routledge and Keegan Paul. 